\title{
Analysis of Efficiency for Zakat Management Organization in Indonesia: A Comparison Study of Super Efficiency and Free Disposal Hull
}

\footnotetext{
Muhamad Nafik Hadi Ryandono

Department of Islamic Economics, Faculty of Economic and Business, Universitas Airlangga
} e-mail: muhammadnafik@feb.unair.ac.id

\section{A Syaiful Qulub}

Department of Islamic Economics, Faculty of Economic and Business, Universitas Airlangga e-mail: muhammadnafik@feb.unair.ac.id

\section{Eko Fajar Cahyono}

Department of Islamic Economics, Faculty of Economic and Business, Universitas Airlangga e-mail: muhammadnafik@feb.unair.ac.id

\section{Tika Widiastuti}

Department of Islamic Economics, Faculty of Economic and Business, Universitas Airlangga e-mail: tika.widyastuti@feb.unair.ac.id

\section{Elsi Mersilia Hanesti}

Universitas Internasional Semen Indonesia

e-mail: elsi.hanesti@uisi.ac.id

\section{Ninda Ardiani}

Department of Islamic Economics, Faculty of Economics and Business, Universitas Airlangga e-mail: ardianinda@gmail.com

Naskah diterima: 8 Desember 2020; direvisi: 22 Juni 2021; disetujui: 16 Juli 2021

\begin{abstract}
Abstrak
Penelitian ini bertujuan untuk menganalisis tingkat efisiensi empat belas Organisasi Pengelola Zakat (OPZ) yang beroperasi di Indonesia. Pendekatan kuantitatif digunakan dengan membandingkan metode Free Disposal Hull (FDH) dan Super Efficiency (SE). Variabel input terdiri dari Socialization expense, Operational Expense, dan Salary Expense, sedangkan penghimpunan dana zakat dan penyaluran zakat merupakan variabel output. Temuan empiris menunjukkan bahwa ZMO Corp 4 merupakan lembaga dengan tingkat efisiensi tertinggi, baik dianalisis dengan metode FDH maupun Super Efficiency. OPZ yang dikelola oleh pemerintah adalah OPZ yang paling efisien dibandingkan dengan yang dikelola oleh grup swasta dan organisasi sosial. Tingkat Total Potential Importance (TPI) menunjukkan bahwa variabel output yang memerlukan penyesuaian paling signifikan adalah penyaluran zakat, yaitu $12,66 \%$.
\end{abstract}

Kata kunci: Efisiensi, Free Disposal Hull, Super Efficiency, Zakat Management Organization

\begin{abstract}
This research aims to analyze the efficiency level of fourteen Zakat Management Organizations (ZMO) in Indonesia. This study uses a quantitative approach with the method of Free Disposal Hull (FDH) and the Super Efficiency (SE) method. Socialization Expense, Operational Expense, and Salary Expense are the input
\end{abstract}


variables, while zakah fund collection and zakah distribution become the output variables. Empirical findings show that ZMO Corp 4 has the highest efficiency level, which analyzed through both methods of FDH or SE. ZMO managed by the government is the most efficient ZMO compared to the others who managed by private group and social organization. Total Potential Importance (TPI) shows that the output variable that requires the most significant adjustment is the zakat distribution, which is $12.66 \%$.

\section{Keywords: Efficiency, Free Disposal Hull, Super Efficiency, Zakat Management Organization}

\section{Introduction}

Some Zakat is a social-economic instrument in Islam that is oriented towards providing benefits to others (Huda, 2016:112). Zakat is one of the appropriate instruments to alleviate poverty not only within the scope of Muslim society but also within the scope of a country. Zakat managed by Zakat Management Organization (ZMO), especially those with formal legal force, would have several advantages (Hafidhuddin, 2002:126) include: (1) Ensuring certainty and discipline of zakat payments, (2) Maintaining feelings of emphathy of mustahiq when dealing directly in receiving zakat from muzakki, (3) Achieving efficiency and effectiveness, as well as the right targets in the use of zakat assets according to the existing priority scale place and (4), Representing the syiar of Islam in the spirit of Islamic governance. The role of Amil in managing ZMO affects the effectiveness and efficiency of the ZMO. Every ZMO must develop performance management and measurement as an effort to oversee the accountability of the ZMO (Noor et al., 2012).

The ZMO continues to develop both in terms of collection and distribution. However, there is still a gap between the potential and realization of the zakat collection. Based on the reported data, the potential of zakat collection in Indonesia has reached 233.8 trillion, while the realization of the collection only covers about 4\% of the potential (BAZNAS, 2021:48). This is due to the distrust from the public towards the ZMO so that the muzakki prefers to channel their zakat funds by themselves. One of these problems can be overcome by ensuring the efficiency of ZMO in managing zakat.

Efficiency is essential for an entity to evaluate and make strategic decision. Recognizing the efficiency of an entity can be related to how the company achieves its goals (Ali \& Ascarya, 2010). The concept of efficiency can be interpreted as the ratio between output and input. The more output resulted from one input will result in a relatively high level of efficiency. According to general economic theory, an entity can be concluded as efficient when it can minimize production costs (input) to produce a certain amount of production (output) or maximize the amount of output by using available production sources. 
In the concept of Islamic economics, efficiency is an effort to achieve the purpose of attaining maqashid sharia. In Islam, efficiency is defined as producing or practising something in the right way, with a fair portion, and not excessively.

The concept of efficiency in the ZMO describes how efficient a zakat management organization in managing and distributing existing zakat funds. The level of effectiveness and efficiency that ZMO shows become one of the community's assessments towards ZMO performance. The level of efficiency of an institution is an exciting aspect to study, including the level of efficiency at ZMO. Several studies examined the level of efficiency of ZMOs. Al-Ayubi et al. (2018) employ the DEA technique to explore the efficiency level of zakat management with socialization expense data, the number of volunteers, the number of zakat funds collected, and zakat distribution as input and output variables. On the other hand, Human Resource Management is an essential part of organizational management. The organized HR management will determine the success of the organization in the future (Rozalinda, 2016).

This study aims to measure the level of efficiency of Zakat Management Organizations (ZMO) in Indonesia through quantitative methods with particular input and output variables using two analysis techniques: Free Disposal Hull (FDH) and Super Efficiency (SE). The use of the Free Disposal Hull analysis technique can provide a more excellent estimation rate of efficiency. At the other hand, Super Efficiency approach is a more complex method that provides a more detailed value of efficiency in order to indicate rating to each object. Based on the Decree of the Minister of Religion Number 333 (2015:5), ZMOs in Indonesia can be established by Islamic-based organizations, Islamic-based foundations, and Islamic-based communities. According to their establishment, this study divides ZMO into three groups: ZMO established by the government, corporations, and social organization. This is to make it easier for researchers in analyzing the ZMO group. In addition, ZMO has a different way of managing zakat based on its affiliation (their establishment). Then, the methods of Super Efficiency and Free Disposal Hull are used to compare and see which ZMO Group has the best efficient value.

Evaluation of zakat management organization would affect the level of efficiency of zakat, and is a crucial aspect of zakat. That effect might include that zakat as an Islamic financial instrument achieving its objectives of socio-economic justice through the wealth distribution mechanism. Through implementation of effective and efficient zakat management, the main goal of the zakat can be achieved, which is to provide a multiplier effect in a multidimensional manner for the welfare of the wider community. 


\section{Research Method}

This study uses a quantitative approach with two methods, namely Super Efficiency (SE) and Free Disposal Hull (FDH). These two techniques are the development of the Data Envelopment Analysis (DEA) analysis method where each method has a broader range of efficiency values so that a more comprehensive ranking order can be derived from each research object. The comparison of the two methods is carried out to see the efficiency value of each ZMO group.

Free Disposal Hull analysis technique is a non-parametric efficiency measurement technique that is considered as generalization of the DEA (Rusydiana, 2019). Free Disposal Hull will produce a broader average of efficiency estimate than DEA (Tulkens, 1993). This efficiency measurement is estimated by looking at the extent to which the production point of a particular Decision-Making Unit (DMU) to the efficient limit point. Efficiency scores are calculated using a scale between $0-1$ or $0-100 \%$. The value of less than 1 (DMU <1) indicates that the DMU is inefficient compared to the other units (Avkiran, 2004).

The Super Efficiency method is a measure of the strength of efficient units that is utilized to rank DMU units as the object of observation (Ruysdiana \& Hasib, 2020). The Super Efficiency method allows the efficiency of the object being observed to have a value of more than 1 or $100 \%$ (Andersen \& Petersen, 1993). This method is used to make a ranking of the DMU unit, which is the object of the research.

The comparison between Free Disposal Hull and Super Efficiency methods in this study is used to determine the level of efficiency of each ZMO when the DMU value is limited and unrestricted. The use of the Free Disposal Hull method provides an efficiency value of one and less so that the ZMO efficiency value seems more efficient with a smaller value. Meanwhile, when using the Super Efficiency method, the efficiency value of the DMU can be more than 1 to infinity, so that the ranking of each efficiency value can be examined. When the ZMO efficiency value is limited using Free Disposal Hull and not determined by the SE, it will provide a comparison of the efficiency level of the ZMO.

The objects observed are 14 ZMOs in Indonesia classified based on their founding group, including ZMOs established by the government, corporations, and social communities. The secondary data is obtained from the 2014-2018 financial statements published on official website of each ZMO. The efficiency of ZMOs is measured through input and output variables. Socialization expense, operational expense, and salary expense are the input variables in this research. Meanwhile, the output variable uses the Zakat Fund and Zakah Distribution Management. The selection of variables is based on the main 
function of the ZMO, namely collecting and distributing zakat using the existing inputs. The sampling technique used in this research is a purposive sampling technique obtained from all ZMO populations operating in Indonesia. The criteria used as a guideline for the sampling are: (1) ZMO which discloses financial reports on its official website, (2) ZMO which publishes financial statements during the study period of 2014-2018 and (3) ZMO that reveals the items of the input and output variables used in this study. Table 1 below explains the classification of ZMO that is included as the objects in this study.

Table 1. Zakat Management Organization (ZMO)

\begin{tabular}{|c|c|c|}
\hline No & Group & Zakat Management Organization \\
\hline 1 & Government & ZMO Gov \\
\hline 2 & \multirow{4}{*}{ Corporation } & ZMO Corp 1 \\
\hline 3 & & ZMO Corp 2 \\
\hline 4 & & ZMO Corp 3 \\
\hline 5 & & ZMO Corp 4 \\
\hline 6 & \multirow{9}{*}{ Social Organization } & ZMO Social 1 \\
\hline 7 & & ZMO Social 2 \\
\hline 8 & & ZMO Social 3 \\
\hline 9 & & ZMO Social 4 \\
\hline 10 & & ZMO Social 5 \\
\hline 11 & & ZMO Social 6 \\
\hline 12 & & ZMO Social 7 \\
\hline 13 & & ZMO Social 8 \\
\hline 14 & & ZMO Social 9 \\
\hline
\end{tabular}

Source: Compiled by author (2020)

The super-efficiency analysis software used in this study is Banxia Frontier Analyst 4.0. Meanwhile, the Free Disposal Hull data analysis in this study used MAXDEA software.

\section{Result and Analysis}

\section{Descriptive Statistic}

The result begins with a descriptive statistical analysis that further can be used to analyze each method's efficiency. Operational expense, socialization expense and salary expense variables become input variables, while zakat fund and zakat distribution are output variables in this study. The average, minimum, and maximum values of each input and output variable can be seen in Table 2 below. 
Table 2. Descriptive Statistics of Research Objects during 2014-2018 (In rupiah)

\begin{tabular}{|c|c|c|c|c|}
\hline \multirow{2}{*}{$\begin{array}{l}\text { Descriptive } \\
\text { statistics }\end{array}$} & \multicolumn{4}{|c|}{ Input } \\
\hline & $\begin{array}{l}\text { Operational } \\
\text { Expense }\end{array}$ & \multicolumn{2}{|c|}{$\begin{array}{l}\text { Socialization } \\
\text { Expense }\end{array}$} & $\begin{array}{l}\text { Human Resource } \\
\text { Expense }\end{array}$ \\
\hline Average & $10,677,305,242$ & \multicolumn{2}{|c|}{$3,825,212,334$} & $7,624,019,383$ \\
\hline Minimum & $12,804,807$ & \multicolumn{2}{|c|}{$5,121,923$} & $11,604,300$ \\
\hline Maximum & $70,001,294,079$ & \multicolumn{2}{|c|}{$23,367,138,542$} & $51,895,788,070$ \\
\hline \multirow{2}{*}{$\begin{array}{l}\text { Descriptive } \\
\text { statistics }\end{array}$} & \multicolumn{4}{|c|}{ Output } \\
\hline & \multicolumn{2}{|l|}{ Zakat fund } & \multicolumn{2}{|c|}{ Zakat distribution } \\
\hline Average & \multicolumn{2}{|c|}{$62,686,113,219$} & \multicolumn{2}{|r|}{$62,365,159,114$} \\
\hline Minimum & \multicolumn{2}{|c|}{$2,594,266,277$} & \multicolumn{2}{|r|}{$2,338,004,030$} \\
\hline Maximum & \multicolumn{2}{|c|}{$229,788,106,390$} & \multicolumn{2}{|r|}{$288,670,038,833$} \\
\hline
\end{tabular}

Sources : Output Software Banxia Frontier Analyst 4.0 and MAXDEA

From the Table 2 it can be see that ZMO spends more funds to finance operational activities compared to the other two input variables with an average expenditure of IDR 10 billion. Meanwhile, the cost for socialization expense is IDR 3.8 billion and expenditures for salary expenses (human resource expense) reaches IDR Rp. 7.6 billion. In the output variable, zakat funds have an average value that is not much different from the value of zakat distribution. The average value of zakat funds collected is IDR 62.6 billion, while the zakat distribution value is IDR 62.3 billion. Financial policy depends on the ZMO management. In the end, this policy will show the extent of the efficiency level of the ZMO.

\section{Efficiency Result of Free Disposal Hull}

Table 3 below describes the level of efficiency using the Free Disposal Hull during the period of 2014-2018. From these results, it can be assumed that ZMO who has a score of 1 on the measurement of the level of efficiency indicates its ability to optimize the input combination for its output production. Conversely, if the result score is less than 1 , this suggests that the ZMO is not efficient, which means that the ZMO has not been able to optimize its input variables to produce maximum output production.

This study measures the level of Free Disposal Hull efficiency based on the ZMO classification according to the type of ZMO. In this study, ZMO is grouped into three groups; ZMO managed by the government, corporation, and social organizations. ZMO managed by 
government not only acts as the regular ZMO, but also has role as a supervisor for other ZMOs. Meanwhile, ZMO managed by a corporation is the ZMO established by private companies. Social organization ZMO is the ZMO managed by a social organization.

Table 3. Average Efficiency of FDH ZMO in Indonesia for 2014-2018

\begin{tabular}{|c|c|c|c|c|c|c|c|c|}
\hline \multirow{2}{*}{ Group } & \multirow{2}{*}{$\begin{array}{l}\text { Zakat Management } \\
\text { Organization }\end{array}$} & \multicolumn{5}{|c|}{ FDH per Year } & \multirow{2}{*}{$\begin{array}{l}\text { Average } \\
\text { FDH }\end{array}$} & \multirow{2}{*}{$\begin{array}{l}\text { RA } \\
\text { NK }\end{array}$} \\
\hline & & 2014 & 2015 & 2016 & 2017 & 2018 & & \\
\hline Goverment & ZMO Gov & 0.787 & 0.868 & 0.772 & 1.000 & 1.000 & 0.885 & 3 \\
\hline \multicolumn{2}{|l|}{ Average } & 0.732 & 0.803 & 0.691 & 1.000 & 1.000 & 0.845 & 1 \\
\hline \multirow{4}{*}{ Corporation } & ZMO Corp 4 & & & 1.000 & 1.000 & 1.000 & 1.000 & 1 \\
\hline & ZMO Corp 1 & & & 0.346 & 1.000 & 1.000 & 0.782 & 4 \\
\hline & ZMO Corp 3 & 1.000 & 0.216 & 0.191 & 0.201 & 0.191 & 0.360 & 8 \\
\hline & ZMO Corp 2 & & & 0.228 & 0.299 & & 0.264 & 10 \\
\hline \multicolumn{2}{|l|}{ Average } & 1.000 & 0.216 & 0.441 & 0.625 & 0.730 & 0.601 & 2 \\
\hline \multirow{9}{*}{$\begin{array}{l}\text { Social } \\
\text { Organization }\end{array}$} & ZMO Social 7 & 0.878 & 1.000 & 1.000 & 1.000 & 1.000 & 0.976 & 2 \\
\hline & ZMO Social 3 & 0.617 & 0.694 & 0.689 & 0.658 & 0.703 & 0.672 & 5 \\
\hline & ZMO Social 9 & & 1.000 & 0.230 & 0.241 & & 0.490 & 6 \\
\hline & ZMO Social 8 & & & 1.000 & 0.181 & 0.198 & 0.460 & 7 \\
\hline & ZMO Social 5 & & & 0.305 & 0.269 & 0.306 & 0.293 & 9 \\
\hline & ZMO Social 2 & & 0.218 & 0.229 & 0.163 & 0.172 & 0.196 & 11 \\
\hline & ZMO Social 4 & 0.179 & 0.185 & 0.150 & 0.171 & 0.125 & 0.162 & 12 \\
\hline & ZMO Social 6 & 0.137 & 0.197 & 0.139 & 0.088 & 0.093 & 0.131 & 13 \\
\hline & ZMO Social 1 & 0.049 & 0.044 & 0.046 & 0.088 & 0.053 & 0.056 & 14 \\
\hline \multicolumn{2}{|l|}{ Average } & 0.372 & 0.477 & 0.421 & 0.318 & 0.331 & 0.382 & 3 \\
\hline \multicolumn{2}{|c|}{ Overall Average } & 0,521 & 0,491 & 0,452 & 0,454 & 0,487 & 0,480 & \\
\hline
\end{tabular}

Source: Output Software MAXDEA. Compiled by Author (2020)

According to the result in Table 3, it can be seen that ZMO Corp 4 for three consecutive years has the highest efficiency value compared to other ZMOs. Although ZMO Corp 4 has only been observed starting in 2016, ZMO Corp 4 can optimize its input to produce its output. Furthermore, ZMO Social 7 and ZMO Government have the second and third highest efficiency levels after ZMO Corp 4 within the 2014-2018 research period. As for each score, the average level of efficiency obtained is 0.976 and 0.885 , respectively. This average level score illustrates that each ZMO is in an efficient position.

Based on the comparison of the average level of efficiency of ZMO seen from the zakat group management, it can be seen that the ZMO managed by the government, namely Zakat Government, has a higher level of efficiency compared to the other ZMO groups, which is 0.885 . Furthermore, in the second position, the highest average efficiency level is obtained by ZMO managed by a company with a score of 0.601 . Meanwhile, the ZMO 
managed by social or community organizations including nine ZMOs have an average level of efficiency of 0.382 .

Free Disposal Hull analysis method is a nonparametric method that measures the level of efficiency of an entity. It can also be used to measure the increase of the capacity within company's production. Table 5 describes the conditions of the Return To Scale (RTS) through the output approach. The RTS conditions that may be experienced by each ZMO are Decreasing Return to Scale (DRS), Constant Return to Scale (CRS), and Increasing Return to Scale (IRS). The DRS condition indicates when there is an increase in input by $1 \%$, there will be an increase the output of less than $1 \%$. On the other hand, the IRS condition indicates that a one percent increase in the input will increase the production for more than $1 \%$ (AlAyubi et al., 2018).

Table 4. Return to Scale ZMO in Indonesia with FDH Analysis for 2014-2018

\begin{tabular}{|c|c|c|c|c|c|c|c|}
\hline \multirow{2}{*}{ No } & \multirow[t]{2}{*}{ Group } & \multirow{2}{*}{$\begin{array}{l}\text { Zakat Management } \\
\text { Organization }\end{array}$} & \multicolumn{5}{|c|}{ Return to Scale } \\
\hline & & & 2014 & 2015 & 2016 & 2017 & 2018 \\
\hline 1 & Government & ZMO Government & DRS & DRS & DRS & DRS & DRS \\
\hline 2 & \multirow{4}{*}{ Corporation } & ZMO Corp 1 & - & - & $D R S$ & $I R S$ & IRS \\
\hline 3 & & ZMO Corp 2 & - & - & $D R S$ & $D R S$ & - \\
\hline 4 & & ZMO Corp 3 & $C R S$ & $D R S$ & $D R S$ & $D R S$ & $D R S$ \\
\hline 5 & & ZMO Corp 4 & - & - & $D R S$ & $D R S$ & $D R S$ \\
\hline 6 & \multirow{9}{*}{$\begin{array}{c}\text { Social } \\
\text { Organization }\end{array}$} & ZMO Social 1 & IRS & IRS & IRS & IRS & IRS \\
\hline 7 & & ZMO Social 2 & - & $D R S$ & $D R S$ & $D R S$ & $D R S$ \\
\hline 8 & & ZMO Social 3 & $D R S$ & $D R S$ & $D R S$ & $D R S$ & $D R S$ \\
\hline 9 & & ZMO Social 4 & - & - & $D R S$ & $D R S$ & $D R S$ \\
\hline 10 & & ZMO Social 5 & $D R S$ & $D R S$ & $D R S$ & $D R S$ & $D R S$ \\
\hline 11 & & ZMO Social 6 & $D R S$ & $D R S$ & $D R S$ & $D R S$ & $D R S$ \\
\hline 12 & & ZMO Social 7 & $D R S$ & $D R S$ & $D R S$ & $D R S$ & $D R S$ \\
\hline 13 & & ZMO Social 8 & - & - & $D R S$ & $D R S$ & $D R S$ \\
\hline 14 & & ZMO Social 9 & - & $D R S$ & $D R S$ & $D R S$ & - \\
\hline
\end{tabular}

Sources : Output Software Banxia Frontier Analyst 4.0 and MAXDEA. Compiled by Author (2020)

Table 4 shows that the ZMO that experienced a constant condition (CRS) was ZMO Corp 3 in 2014. However, ZMO Corp 3 was unable to maintain the CRS condition in the 20152018 period and experienced the situation of decline (DRS). A different condition occurs in ZMO Social 1 where during the study period, ZMO Social 1 experienced a case of increasing production capacitation (IRS) in a row. If we look at the comparison scores included in the 
Table 4, it can be seen that the ZMO Social 1 on average has the lowest level of efficiency compared to the other 13 ZMOs. Meanwhile, the level of production capacity in 13 ZMOs was in the state of declines (DRS).

\section{Efficiency Result of Super Efficiency}

Table 5 shows the measurement of the ZMO efficiency level using the Super Efficiency method during the period of 2014-2018. This research was conducted based on the ZMO classification based on the zakat management group. The results of the analysis in Table 5 above show that the ZMO that has the highest level of efficiency is the ZMO managed by the government, namely ZMO Government (0.999). Meanwhile, ZMO in the second position was ZMO managed by the company (0.788). Moreover, ZMO managed by ZMO social organization is in third place, with an average level of efficiency of 0.414 .

Table 5. Efficiency Level of ZMO in Indonesia with Super Efficiency Method

\begin{tabular}{|c|c|c|c|c|c|c|c|c|}
\hline \multirow{2}{*}{ Group } & \multirow{2}{*}{$\begin{array}{l}\text { Zakat Management } \\
\text { Organization (ZMO) }\end{array}$} & \multicolumn{5}{|c|}{ Super Efficiency per Year } & \multirow{2}{*}{$\begin{array}{l}\text { Average } \\
\text { SE }\end{array}$} & \multirow{2}{*}{ Rank } \\
\hline & & 2014 & 2015 & 2016 & 2017 & 2018 & & \\
\hline Government & ZMO Gov & 0.765 & 0.846 & 0.750 & 1.130 & 1.505 & 0.999 & 4 \\
\hline \multicolumn{2}{|r|}{ Average } & 0.765 & 0.846 & 0.750 & 1.130 & 1.505 & 0.999 & 1 \\
\hline \multirow{4}{*}{ Corporation } & ZMO Corp 1 & & & 1.180 & 1.077 & 1.237 & 1.165 & 1 \\
\hline & ZMO Corp 2 & - & - & 0.324 & 1.311 & 1.762 & 1.132 & 2 \\
\hline & ZMO Corp 3 & 2.360 & 0.194 & 0.169 & 0.179 & 0.169 & 0.614 & 7 \\
\hline & ZMO Corp 4 & & & 0.206 & 0.277 & & 0.242 & 10 \\
\hline \multicolumn{2}{|r|}{ Average } & 2.360 & 0.194 & 0.470 & 0.711 & 1.056 & 0.788 & 2 \\
\hline \multirow{9}{*}{$\begin{array}{l}\text { Social } \\
\text { Organization }\end{array}$} & ZMO Social 1 & 0.856 & 0.978 & 1.036 & 1.125 & 1.042 & 1.007 & 3 \\
\hline & ZMO Social 2 & & & 2.360 & 0.159 & 0.176 & 0.898 & 5 \\
\hline & ZMO Social 3 & 0.595 & 0.672 & 0.667 & 0.636 & 0.681 & 0.650 & 6 \\
\hline & ZMO Social 4 & & 0.969 & 0.208 & 0.219 & & 0.465 & 8 \\
\hline & ZMO Social 5 & & & 0.283 & 0.247 & 0.284 & 0.271 & 9 \\
\hline & ZMO Social 6 & & 0.196 & 0.207 & 0.141 & 0.150 & 0.174 & 11 \\
\hline & ZMO Social 7 & 0.157 & 0.163 & 0.128 & 0.149 & 0.103 & 0.140 & 12 \\
\hline & ZMO Social 8 & 0.115 & 0.175 & 0.117 & 0.066 & 0.071 & 0.085 & 13 \\
\hline & ZMO Social 9 & 0.027 & 0.022 & 0.024 & 0.066 & 0.031 & 0.034 & 14 \\
\hline \multicolumn{2}{|r|}{ Average } & 0.507 & 0.703 & 0.933 & 0.413 & 0.440 & 0.414 & 3 \\
\hline \multicolumn{2}{|c|}{ Overall Average } & 0,696 & 0,468 & 0,547 & 0,484 & 0,601 & 0,563 & \\
\hline
\end{tabular}

Sources : Output Software Banxia Frontier Analyst 4.0. Compiled by Authors (2020)

The results show that the ZMO with the highest level of efficiency during the 20162018 observation period is the ZMO Corp 4 with the highest average efficiency level compared to other fourteen ZMOs, which is 1,165. Apart from ZMO Corp 4, ZMO Social 7 
has the high efficiency values for three consecutive periods from 2016-2018, with an average level of efficiency 1,007. Besides, the results of efficiency level measurement show that in the year of 2017 the highest efficiency is achieved by ZMO Social 7, which is 1,125.

The year 2016 is the period where the most of ZMO had an experience in achieving an efficient value. The ZMO with efficiency in that year was ZMO Social 8 (2,360). ZMO Social 7 (1,058) and ZMO Corp 4 (1,036). In 2017 and 2018, three ZMOs had efficient values, namely the ZMO Government, ZMO Social 7, ZMO Corp 1 and ZMO Corp 4. As for 2014, only one ZMO was in an efficient condition, namely ZMO Corp 3 with Super Efficiency results obtained of 2,360.

Overall, most of the ZMO in Indonesia has an efficiency level that is still far from the expected efficiency. This is concluded by looking at the results of data processing using the Super Efficiency method. Only three ZMOs have an average efficiency above 1, and they are ZMO Corp 4 (1,165), ZMO Corp 1 (1,132), and ZMO Social 7 (1,007). This illustrates that the three ZMOs successfully carried out optimal input management without reducing their output. On the other hand, the three ZMOs have not obtained maximum efficiency compared to the other $10 \mathrm{ZMOs.}$

Table 6. Return to Scale ZMO in Indonesia with Super Efficiency Analysis for 20142018

\begin{tabular}{|c|c|c|c|c|c|c|c|}
\hline \multirow{2}{*}{ No } & \multirow[t]{2}{*}{ Group } & \multirow{2}{*}{$\begin{array}{c}\text { Zakat Management } \\
\text { Organization }\end{array}$} & \multicolumn{5}{|c|}{ Return to Scale } \\
\hline & & & 2014 & 2015 & 2016 & 2017 & 2018 \\
\hline 1 & Government & ZMO Government & IRS & IRS & IRS & CRS & CRS \\
\hline 2 & \multirow{4}{*}{ Corporation } & ZMO Corp 1 & & & IRS & $C R S$ & CRS \\
\hline 3 & & ZMO Corp 2 & & & IRS & IRS & \\
\hline 4 & & ZMO Corp 3 & $C R S$ & IRS & IRS & IRS & $\operatorname{IRS}$ \\
\hline 5 & & ZMO Corp 4 & & $I R S$ & $I R S$ & IRS & \\
\hline 6 & \multirow{9}{*}{ Social organization } & ZMO Social 1 & IRS & IRS & IRS & IRS & IRS \\
\hline 7 & & ZMO Social 2 & & IRS & IRS & IRS & IRS \\
\hline 8 & & ZMO Social 3 & IRS & IRS & IRS & IRS & IRS \\
\hline 9 & & ZMO Social 4 & & & IRS & IRS & IRS \\
\hline 10 & & ZMO Social 5 & IRS & IRS & IRS & IRS & IRS \\
\hline 11 & & ZMO Social 6 & IRS & IRS & $C R S$ & $C R S$ & $C R S$ \\
\hline 12 & & ZMO Social 7 & IRS & IRS & IRS & IRS & IRS \\
\hline 13 & & ZMO Social 8 & & & $C R S$ & $I R S$ & $\operatorname{IRS}$ \\
\hline 14 & & ZMO Social 9 & & & $C R S$ & $C R S$ & $C R S$ \\
\hline
\end{tabular}

Source : Output Software Banxia Frontier Analyst 4.0 and MAXDEA. Compiled by Author (2020) 
Table 6 above shows that zakat management organization has experienced a different scale to return condition analysed through the Free Disposal Hull technique. However, by using the approach of Super Efficiency techniques, it can be seen that the zakat management organization tends to have IRS and CRS conditions. ZMO Social 1, ZMO Social 3, ZMO Social 6, and ZMO Social 4 have IRS conditions for five consecutive years from 2015 to 2018. This indicates that every additional $1 \%$ output will result in more than $1 \%$ input.

\section{Efficiency Results with Super Efficiency and Free Disposal Hull Methods}

Following the background of the research described earlier, this study compares the efficiency of ZMOs in Indonesia using Super Efficiency and Free Disposal Hull methods. Each method has different characteristics so that the comparison of the two methods produced data results, as shown in table 7 below:

Table 7. Super Efficiency vs Free Disposal Hull

\begin{tabular}{|c|c|c|c|c|c|}
\hline \multirow[b]{2}{*}{ Group } & \multirow{2}{*}{$\begin{array}{l}\text { Zakat management } \\
\text { Organization }\end{array}$} & \multicolumn{2}{|c|}{ Super Efficiency } & \multicolumn{2}{|c|}{ Free Disposal Hull } \\
\hline & & Avg SE & Rank & $\begin{array}{l}\text { Avg } \\
\text { FDH }\end{array}$ & Ranking \\
\hline Government & ZMO Government & 0.999 & 4 & 0.885 & 3 \\
\hline \multirow{4}{*}{ Corporation } & ZMO Corp 1 & 1.132 & 2 & 0.782 & 4 \\
\hline & ZMO Corp 2 & 0.242 & 10 & 0.264 & 10 \\
\hline & ZMO Corp 3 & 0.614 & 7 & 0.360 & 8 \\
\hline & ZMO Corp 4 & 1.165 & 1 & 1.000 & 1 \\
\hline \multirow{9}{*}{$\begin{array}{l}\text { Social } \\
\text { organization }\end{array}$} & ZMO Social 1 & 0.034 & 14 & 0.056 & 14 \\
\hline & ZMO Social 2 & 0.174 & 11 & 0.196 & 11 \\
\hline & ZMO Social 3 & 0.650 & 6 & 0.672 & 5 \\
\hline & ZMO Social 4 & 0.271 & 9 & 0.293 & 9 \\
\hline & ZMO Social 5 & 0.085 & 13 & 0.131 & 13 \\
\hline & ZMO Social 6 & 1.007 & 3 & 0.976 & 2 \\
\hline & ZMO Social 7 & 0.140 & 12 & 0.162 & 12 \\
\hline & ZMO Social 8 & 0.898 & 5 & 0.460 & 7 \\
\hline & ZMO Social 9 & 0.465 & 8 & 0.490 & 6 \\
\hline
\end{tabular}

Sources : Output Software Banxia Frontier Analyst 4.0. Compiled by Authors (2020)

One indicator to assess the performance of a company is to see the level of efficiency of the business processes. Likewise, in Zakat Management Organization (ZMO), assessment of the level of efficiency of ZMO is essential for the internal evaluation of ZMO. This study compares the results of the Super Efficiency and Free Disposal Hull tests, where these two 
methods are an extension of the Data Envelopment Analysis method. The Super Efficiency method is used to see the level of efficiency performance of a ZMO by displaying a level of efficiency that allows more than $100 \%$. The obtained DMU efficiency score shows that the DMU efficiency is measured through the number of inputs to produce outputs and then compared to other DMUs. The Free Disposal Hull method is a nonparametric method that functions to measure the level of efficiency of an entity as well as increase the company's production capacity by looking at the level of return to scale (RTS) compared to the output approach. Based on the results, the second rank of each method is occupied by two different ZMOs. ZMO Corp 1 ranks in second using the Super Efficiency method. Meanwhile using the Free Disposal Hull method, the Zakat House ranks in second. This difference can be caused by the limitation of each method's efficiency value and the length of time observed.

In the Super Efficiency method, ZMO Corp 1 was ranked in second place in terms of the village level. During the observation period of 2017-2018, it had a value above 1, which indicates that ZMO Corp 1 was already efficient. In 2016, the efficiency value of ZMO Corp 1 was 0.324 . However, in the Free Disposal Hull method, ZMO Corp 1 is in the fourth place with an average value of 0.782 . In 2016, the efficiency value of ZMO Corp 1 using the Free Disposal Hull method was 0.346. Meanwhile in the following year, the efficiency value of ZMO Corp 1 was in number 1. Although each method has showed efficiency in 2017-2018, the Free Disposal Hull method's limitations might cause the average value of ZMO Corp 1 to rank in fourth.

ZMO Social 7 ranks third in the SE method, while when using the Free Disposal Hull method, it is in second place. Not much different from the previous ZMO Corp 1, this difference in ranking during comparison could be due to the limitation of each method's efficiency value and the length of observation time period. ZMO is said to be efficient when it has a value of 1 or more than 1. ZMO Corp 1 and Zakat Houses have the CRS condition between 2017 and 2018 analyzed using both methods. This indicates that each additional input of $1 \%$ will increase output by $1 \%$ as well.

ZMO Corp 4 is a ZMO that manages zakat, infaq, shadaqah, and waqf (ZISWAF) of a corporation. It has the vision to empower mustahiq in becoming muzakki. Based on data from the ZMO Corp 4 annual report in 2018, the amount of ZISWAF fundraising until the end of 2018 reached IDR 239 billion or the same as an increase by Rp. 66.5 B (38.5\%) from 2017. The source of the ZISWAF collection itself comes from the zakat of employees through payroll and non-payroll, infaq and cash waqf from employees. ZISWAF from nonemployees with a total number of muzakki as of December 2018 has reached 33,616 people 
(an increase of 21\% from 2017). The high level of efficiency obtained by ZMO Corp 4, both using the Free Disposal Hull or Super Efficiency method, can be affected by the fundraising system of their institution that is implemented through its corporation's payroll system. The existence of payroll system that is required for employees who have an income reaching the nisab makes it easier for the ZMO (Saharuddin et al., 2019). The payroll system is designed right on the targets who are obliged to perform zakat. Besides, this ZMO also has averagely low socialization expenses and operational costs. In 2018, ZMO Corp 4 succeeded to collect the largest collection of zakat funds among other ZMOs included in this study.

In terms of distribution and utilization of zakat, ZMO Corp 4 has various programs, namely: Economy (12 programs), Health (9 courses), Education (10 programs), Social Humanity (13 programs), Dakwah (9 programs). With these various distribution programs, in 2018 the amount of ZMO Corp 4 disbursement is Rp202 billion or an increase of Rp50.8 billion (33.35\%) from 2017. In 2018, ZMO Corp 4 give priority on the distribution and utilization of ZISWAF funds into two main groups of asnaf, namely: the disadvantaged and the poor, with the consideration that ZISWAF funds will be very much needed and have an acceleration of distribution in terms of fulfilling urgent necessity and demand. ZMO Corp 4 also pays attention to the other six asnaf groups.

Table 8. Super Efficiency vs FDH

\begin{tabular}{|l|c|c|}
\hline \multirow{2}{*}{\multicolumn{1}{|c|}{ Zakat Management Operational }} & \multicolumn{2}{c|}{ Ranking } \\
\cline { 2 - 3 } & Super Efficiency & FDH \\
\hline Average government & 1 & 1 \\
\hline Average Corporate & 2 & 2 \\
\hline Average Social organization & 3 & 3 \\
\hline
\end{tabular}

Sources: Data arranged by Author (2020)

It can be seen from the Table 8 above, the average efficiency ranking from the data process using the Super Efficiency method for ZMO established by the government group is the most efficient among other groups. This result is not much different from the results of the analysis of the Free Disposal Hull method. ZMO managed by the government is the group with the highest level of efficiency, followed by the corporate and social organization groups. The efficiency of ZMO managed by government is because the primary activity or main business at the organization is to manage zakat funds. Apart from that, ZMO Government can also be a facilitator and regulator for other ZMOs. The main segments of ZMO Government are officials and employees in the government-related such as officials, bureaucrats, civil servants in the district/city governments with a payment mechanism for 
zakat (zakat maal). The payment can be done by directly deducting the salaries with the approval of the civil servants or direct payments. It is voluntary by the civil servants who concerned. In reality, not all civil servants distribute their zakat through ZMO Government, and ZMO Government also receive zakat paid by the general public. ZMO Corporate ranks second in the efficiency of zakat fund management, reflected in the YBM PLN ranking as being the best in terms of ZMO efficiency.

Table 8 also shows that, on average, the ranking of ZMO managed by corporate group is in second place. ZMO who is in the corporate group in this study include ZMO Corp 1, ZMO Corp 2, ZMO Corp 3, and ZMO Corp 4. Still, there are not many corporations that have established ZMO. Generally, ZMO who established within a corporate group, has the convenience of collecting zakat. One example is ZMO Corp 4, where every employee who is obliged to do zakat will have their income deducted automatically to pay for zakat through ZMO Corp 4. This payment convenience has a significant impact on the level of efficiency at ZMO Corp 4, which makes it easier to distribute zakat, and for ZMO Corp 4 itself to collect existing zakat funds. Apart from ZMO Corp 4, ZMO Corp 2 put an effort to collect zakat funds to be better organized through customers's bank account. ZMO Corp 2 customers can channel their zakat funds through ZMO Corp 2, which is already connected to the bank's services. ZMO, who are in the corporate group, generally makes it easier for their stakeholders to distribute zakat. The convenience offered can put less pressure on operational costs and human resources to optimize the collection and distribution of the existing zakat funds.

Furthermore, $\mathrm{ZMO}$ who is in the third rank is the ZMO managed by social organization group. ZMO from this group is generally established by social organization groups whose goal is to manage zakat funds. ZMO in this group is usually spread across Indonesia. Each region has branch offices of some of these ZMOs. The distribution of branch offices of several ZMOs is to generalize the management of zakat so that it is not only focused on one particular area. However, some of these ZMOs are still not efficient in managing their zakat funds. The number of branch offices in the regions can provide relatively high operational expense.

Unlike the ZMO in the corporate group, where in the corporate ZMO the stakeholders can easily collect zakat funds from their employees, ZMOs from social organization groups might collect zakat funds from the wider community. However, the muzakki they serve are not sure the same as the corporate ZMO. Muzakki who comes from the ZMO social organization group is generally from the household or entrepreneur. The broader distribution 
of society included can cause the number of muzakki and the collection of zakat funds from this group to have a smaller amount than the collection of zakat funds from the corporate group. Also, the operational costs incurred by the ZMO from the social organization group are significantly higher. Besides, people who are obliged to do zakat usually distribute their zakat directly to mustahiq, so that it is not recorded in the financial statements of each ZMO.

Although ZMO from a social organization is in the third rank, the existence of a ZMO social organization is needed to manage zakat in the various regions so that zakat can be appropriately managed. This wide distribution may provide more benefits. ZMO social organization has a business focus on managing zakat and empowering people so that every management activity is aimed at optimizing existing zakat funds to help mustahiq.

The efficiency of an organization cannot be separated from the concept of governance that exists within organization where it is related to the existing input management process to achieve maximum and useful output. It has been mentioned in the previous section that the input variables used include: operations, socialization and salary expenses. Obviously these three inputs will be related and impacted on the output variables, namely: zakat collected and zakat distributed. To achieve optimal efficiency, it is necessary to optimize and implement good governance internally and externally. The effectiveness and efficiency of $\mathrm{ZMO}$ has an integral part of achieving the goal of reducing poverty as well as mustahiq. ZMO must be effective, efficient, socialized, and has a significant impact on poverty alleviation and improving the welfare of mustahiq (Al Ayubi et al., 2018).

Table 9. Total Potential Improvement of Super Efficiency and FDH

\begin{tabular}{|c|c|c|}
\hline \multirow{2}{*}{$\begin{array}{c}\text { Zakat Management } \\
\text { Operational }\end{array}$} & \multicolumn{2}{|c|}{ Total Potential Improvement } \\
\cline { 2 - 3 } & Super Efficiency & FDH \\
\hline Socialization Expense & $-27.4 \%$ & $-29.47 \%$ \\
\hline Operational Expense & $-28.08 \%$ & $-27,96 \%$ \\
\hline Human Resource Expense & $-27.28 \%$ & $-27.64 \%$ \\
\hline Zakah Fund & $4.58 \%$ & $3.57 \%$ \\
\hline Zakah Distribution & $12.66 \%$ & $11.36 \%$ \\
\hline
\end{tabular}

Source: Arranged by Author (2020)

Following the Total Potential Importance analysis result using the Super Efficiency method, the output variable which requires the most significant adjustment, is the distribution of zakat funds. To achieve an optimal efficiency level, ZMO must increase the number of zakat funds distributed by $12.66 \%$ and increase the number of funds raised by $4.58 \%$. However, special attention is needed for internal ZMO related to the distribution of 
zakat funds from these muzakki. This is in line with the goal of the ZMO, which is to create prosperity by optimizing the distribution of zakat funds. The test results indicate that the internal ZMO has not optimally utilize in distributing zakat funds to muzakki, so it needs to be increased by $12.66 \%$. Meanwhile, the Total Potential Importance by using the Super efficiency method, to achieve efficiency, each ZMO must reduce salary expenses by $27.28 \%$; the operational cost by $28.08 \%$ and socialization expense by $27.64 \%$. Not much different from the Super Efficiency method, by using the Free Disposal Hull method to achieve a better efficiency level, each ZMO reduces socialization expansion by $29.47 \%$, operational expense by $27.96 \%$, and human resource expansion by $27.64 \%$. Besides, in reducing existing costs ZMO must also strive to increase zakat funds by $3.57 \%$ and distribution zakat by $11.36 \%$.

This means that the zakat funds collected are more significant than the zakat funds distributed by ZMO. Various factors could cause the distribution of zakat funds to be not optimal, including the lack of data of ashnaf, demographic characteristics of ashnaf, and the lack of understanding of amil regarding the classification of the eight ashnaf. Also, muzakki generally channel their zakat funds directly to mustahiq rather than channel their funds through ZMOs. Therefore, ZMOs must improve zakat management and optimize existing inputs in achieving efficiency. This has to be done to increase public trust towards ZMO so that fundraising increases and more funds can be distributed.

When viewed from the distribution of the population in Indonesia, the number of people from middle to lower-income and poor communities is still relatively high. So, it is impossible to say that the number of muzakki is greater than the number of mustahiq. This is also a sign that the social gap between the rich and the poor is quite large. For example, currently many students need education funding assistance which actually can be fulfilled from these zakat funds. However, in fact the distribution of zakat funds has not been optimal. This shows the need to improve communication and access between the two parties, the muzakki and the mustahiq. The fact is supported by the research result from Widiastuti et al. (2021) which mentions the lack of information on the whereabouts of mustahik and what ZMOs needs.

It is better if ZMO has a specialization in empowerment to distribute their zakat funds so that the support for mustahiq can be more optimally done. As technology develops, it takes ways and efforts from each $\mathrm{ZMO}$ to provide convenience to each muzakki or mustahiq to distribute zakat funds and empower them. The use of this technology can reduce costs to optimize the collection and distribution of existing zakat 
funds. Yahaya \& Ahmad (2019) stated that the use of technology such as mobile banking is a solution in increasing zakat collection because of the ease of access and cost-savings. This is also in line with Widiastuti et al. (2021) research who found the need for the ability to use technology as a solution for optimizing zakat management.

Optimization in the management of zakat funds will have a good impact on every aspect, especially on economic growth. The role of ZMO as amil zakat is demanded not only to provide convenience in distributing zakat but also to provide services for muzakki, in this case, openness or transparency in the use of the funds they manage. The clearer transparency of managed funds will increase the confidence of muzakki on utilizing each ZMO (Nasri et al., 2019; Amalia \& Widiastuti, 2020).

Honesty has been discussed in various disciplines; this is done to test the relationship of honesty with many factors that affect specific fields of knowledge (Suud \& Madjid, 2020). One of the impacts is that ZMO's ability to distribute zakat funds will later influence the level of public trust in ZMO and will subsequently have an effect on the amount of zakat collected (Ghazali et al., 2016). Therefore, in addition to maximize the zakat collected, ZMO needs to optimize efforts to distribute these zakat funds. From the distribution of zakat, the community will assess the ability of ZMO in managing and making programs so that the zakat distributed reaches the right target of mustahiq and provides direct benefits to the mustahiq. This factor is often a consideration for muzakki in issuing their zakat, whether through ZMO or by channeling it directly to those around them who are in need. Apart from being right on target, there is also an "experience" that muzakki immediately gets on distributing zakat.

\section{Conclusion}

From the result of data processing, using both of Free Disposal Hull and Super Efficiency methods, it is found that one of the ZMO established by the company is the most efficient ZMO (highest efficiency level). Fourteen ZMOs are grouped into three groups, namely government, corporate and social organization. Based on the average value from each of these groups, ZMO established by the government is the ZMO with the highest level of efficiency, followed by ZMO managed by corporation and ZMO from the social organization.

This study also finds that ZMOs from all groups need to consider using inputs to produce optimal outputs. The amount of zakat collected and distributed needs to be considered in addition to optimize the use of costs. Suggestion from this study is that ZMO 
can be more focused on managing zakat funds and zakat distribution by providing additional technology or convenience in every aspect. Also, it is hoped that there will be better coordination between ZMO Government, ZMO Corporate, and ZMO Social organizations. The limitations of this study are that it does not measure the efficiency of all ZMOs in Indonesia. However, in general, the result of efficiency analysis can be used as a reference for decision-making to achieve efficient ZMO management. Meanwhile, for the academic or researcher, we suggest another research with different periods or different methods of ZMO efficiency.

\section{Acknowledgment}

The authors would like to appreciate the Research and Innovation Centre and Faculty of Economics and Business Universitas Airlangga for financial support. The authors also would like to thank Mr. Muhammad Ubaidillah Al Mustofa and Mrs. Nikmatul Atiya for their comments and advices to improve this paper.

\section{Bibliography}

Al-Ayubi, S., Ascarya, \& Possumah, B. T. (2018). Examining the Efficiency of Zakat Management: Indonesian ZMOs Experiences. International Journal of Zakat, 3(1), 3755. https://doi.org/10.37706/ijaz.v3i1.66

Ali, M. M., \& Ascarya. (2010). Analisis Efisiensi Baitul Maal Wat Tamwil Dengan Pendekatan Two Stage Data Envelopment Analysis (Studi Kasus Kantor Cabang BMT MMU Dan BMT UGT Sidogiri). TAZKIA: Islamic Finance \& Business Review, 5(52), 110-125. http://dx.doi.org/10.30993/tifbr.v5i2.44

Amalia, N., \& Widiastuti, T. (2020). Pengaruh Akuntabilitas, Transparansi, Dan Kualitas Pelayanan Terhadap Minat Muzaki Membayar Zakat. Jurnal Ekonomi Syariah Teori Dan Terapan, 6(9), 1756. https://doi.org/10.20473/vol6iss20199pp1756-1769

Andersen, P., \& Petersen, N. C. (1993). A Procedure for Ranking Efficient Units in Data Envelopment Analysis. Management Science, 39(10), 1261-1264. https://doi.org/10.1287/mnsc.39.10.1261

Avkiran, N. k. (2004). Decomposing Technical Efficiency and Window Analysis. Studies in Economics and Finance, 22(1), 61-91. https://doi.org/10.1108/eb043383

BAZNAS. (2021). Outlook Zakat Indonesia 2021. Pusat Kajian Strategis - Badan Amil Zakat Nasional (PUSKAS BAZNAS).

Decree of the Minister of Religion Number 333 of 2015 concerning Guidelines for Granting Permits to Establish ZMOs, 1 (2015).

Ghazali, M. Z., Saad, R. A. J., \& Wahab, M. S. A. (2016). A Conceptual Framework for Examining Trust towards ZMO. International Journal of Economics and Financial Issues, 6(S7), 98-102. http:www.econjournals.com 
Hafidhuddin, D. (2002). Zakat Dalam Perekonomian Modern. Gema Insani.

Huda, N. (2016). Keuangan Publik Islam: Pendekatan Teoritis dan Sejarah (2nd ed.). Kencana. https://books.google.co.id/books?hl=id\&lr=\&id=CPSIDwAAQBAJ\&oi=fnd\&pg=PR $1 \& \mathrm{dq}=$ Keuangan+Publik+Islam:+Pendekatan+Teoritis+dan+Sejarah\&ots=ubgVXGr7 iL\&sig=x9uI51bTm0YYwDvfDbkRgREpzgU\&redir_esc=y\#v=onepage\&q=Keuanga n Publik Islam\%3A Pendekatan Teoritis dan Seja

Nasri, R., Aeni, N., \& Haque, M. G. (2019). Determination of Professionalism and Transparency and Its Implications for the Financial Performance of ZMOs. Journal of Islamic Monetary Economics and Finance, 5(4), 785-806. https://doi.org/10.21098/jimf.v5i4.1158

Noor, A. H. M., Rahman, R. A., Yusof, R. M., \& Ali, S. M. (2012). Assessing Performance of Nonprofit Organization: A Framework for ZMOs. British Journal of Economics, Finance and Management Sciences, 5(1), 12-22. https://doi.org/10.1613/jair.301

Rozalinda. (2016). Konsep Manajemen Sumber Daya Manusia : Implementasi Pada Industri Perbankan Syariah Rozalinda. Al-Masraf : Jurnal Lembaga Keuangan Dan Perbankan, 1(1), 107-124. http://journal.febi.uinib.ac.id/index.php/almasraf/article/view/28

Rusydiana, A. S. (2019). Efisiensi Sosial Dan Finansial Bank Syariah Di Indonesia: Pendekatan Nonparametrik. Riset Akuntansi Dan Keuangan Indonesia, 4(1), 13-24. https://doi.org/10.23917/reaksi.v4i1.6814

Ruysdiana, A. S., \& Hasib, F. F. (2020). Super Efisiensi dan Analisis Sensitivitas DEA: Aplikasi Pada Bank Umum Syariah Di Indonesia. Amwaluna: Jurnal Ekonomi Dan Keuangan Syariah, 4(1), 41-54. https://doi.org/10.1017/CBO9781107415324.004

Saharuddin, D., Anggraini, R. T., \& Jamila, S. (2019). Efficiency and Effectiveness of Zakat Payroll System and Digital Zakat on the Acceptance of Zakat Funds BAZNAS 20162017. Maqdis: Jurnal Kajian Ekonomi Islam, 4(1), 36-44.

Suud, F. M., \& Madjid, A. (2020). Honesty: A Multidimensional Study as Motivation for National Character Building. Hayula: Indonesian Journal of Multidisciplinary Islamic Studies, 4(1), 99-116. https://doi.org/10.21009/004.01.06

Tulkens, H. (1993). On FDH Efficiency Analysis: Some Methodological Issues and Applications to Retail Banking, Courts, and Urban Transit. Journal of Productivity Analysis, 4(1-2), 183-210. https://doi.org/10.1007/BF01073473

Widiastuti, T., Cahyono, E. F., Zulaikha, S., Mawardi, I., \& Al Mustofa, M. U. (2021). Optimizing Zakat Governance in East Java using Analytical Network Process (ANP): The Role of Zakat Technology (ZakaTech). Journal of Islamic Accounting and Business Research, 12(3), 301-319. https://doi.org/10.1108/JIABR-09-2020-0307

Yahaya, M. H., \& Ahmad, K. (2019). Factors Affecting the Acceptance of Financial Technology among Asnaf for the Distribution of Zakat in Selangor - A Study Using UTAUT. Journal of Islamic Finance, Special Issue, 35-46. 
